\title{
Revisiting English Competence at Hotel
}

\author{
Afrianto $^{1}$, Ingatan Gulö ${ }^{2}$ \\ afrianto@teknokrat.ac.id ${ }^{1}$, afrianto@teknokrat.ac.id ${ }^{2}$ \\ Universitas Teknokrat Indonesia
}

\begin{abstract}
This study aims at coming up with English competence at hotel. Going along with that aim, this study focuses on one hotel in Bandar Lampung which has been developing; it is Novotel hotel. This chosen hotel meets with the criteria of hotel targeted. Further, this study was conducted qualitatively because it pursued deep findings dealing with English competence of some duties in hotel, such as reception and handling guest. Besides, questioner was employed to gather data and then interview was also conducted to have more concrete data. At last, this study came up with the detail findings of the average of English proficiency based on the positions. Furthermore, this study formulated the common expressions used to host and serve customers.
\end{abstract}

Keywords: English competence, English for hotel hospitality

\section{Introduction}

Along with the development of tourism, an increasing number of both domestic and foreign tourists coming to Lampung is also an indicator of the development of hotels. Dealing with the foreign tourists who are not all able to speak in bahasa Indonesia, generally hotels need human resource who can meet with requirements especially English mastery in some positions, such as receptionist, operator, bellboy, and room servicer. Further, to be an international hotel with a particular high star, a hotel needs to use English in all kinds of services. Based English communication, all lines of service must at least know expressions used in hotels.

In a research conducted by Brunton (2009) in a five-star hotel in Thailand, he found that the application of English for Specific Purpose is better than General English. It means that ESP is more specific and based on the needs of hotel hospitality. Dealing with the service, there are some research conducted. One of them was managed by Hai-yan and Baum (2006) and it was conducted in China and focused on front office. They came up with three points; 1) hospitality industry in China lacked of professionals (bachelor or higher degree); 2) career prospect; and 3) course of front office. These three points define how important the professional hotel personnel is, especially in front office dealing with service. Further, there is also a research conducted by M. Ariffin, Maghzi \& Aziz (2011) to figure out the hotel hospitality toward local and foreign guests at four and five starts in Kuala Lumpur. They posit that personalization, comfort and warm welcoming are the dimensions of hotel hospitality, then they also state that dealing with hotel hospitality local guests have more expectation than the foreign guests. It means that hotel hospitality takes a role in satisfying the guests, thus this matter deals with hotel personnel. Simply, hotel hospitality can be well established as long as hotels have professional personnel who are willing to do so.

Moreover, there is another factor which determines hotel hospitality, it is language. M. Blue and Harun (2003) conducted a case study of four hotels in Southampton dealing with hospitality language. They argue that particular patterns of language are associated with host-guest interaction. Then they also posit that hospitality language skill can be approached with such a training categorized as an ESP (English for Specific Purposes) or EOP (English 
for Occupational Purposes). This case study is conducted in UK, therefore they mainly discussed English. Further, nowadays global travel is happening, therefore this situation requires a means of communication which is language. Thus, English is the very possible one to meet with this requirement.

Concerning with English communication in hotels, this research tried to dig up English competence in some hotel hospitalities; such as greeting, offering help, explaining hotel facilities and responding complain. Those four types of competences are both basic and common. Each personnel of hotel has to be able to do so. Therefore, this research focuses on the competences in some positions which directly face and serve guests especially foreigners.

\section{Method}

Aiming at describing English competence in Novotel hotel, this research employed qualitative method. It is in line with Croker (2009), he states that qualitative method is characterized as an explanatory way with the purpose to figure out pattern of behavior and thinking. Further, Duff (2008) posits that qualitative method is applied to comprehend people or community in a particular natural setting. Along with Duff, Stake (2010:11) argues that research directed qualitatively mainly lies its focus on human perception and understanding. This is also what this research designs, it goes deeply to capture people's ability especially English for hotel. Gathering data, this research applies questionnaire which has two types of question, they are closed and open-ended question (Wilkinson and Birmingham, 2003: 11). The closed question is designed to know whether or not the participants use English to serve the foreign guests. It is because this question requires an answer; "yes" or "no". On another hand, the open-ended one is to pattern the common English expressions used in giving services in the hotel. Further, the questionnaire consists of four items, which cover the research question; they are greeting, offering help, explaining hotel facilities and general knowledge of city and responding complains. Then there are 10 questions altogether.

\section{Findings and Discussion}

Dealing with foreign tourists who are not all able to speak in bahasa Indonesia (the researchers prefer using Indonesian), this is of course a consideration for hotel developer/owner to recruit people with good English competence. Concerning with such a situation, this research tried to trace the hotel personnels' English capability in the targetted hotel, i.e. Novotel Hotel. To make it specific, this research focuses on some selected positions; they are operator, receptionist, Bellboy, Waitress, and Pool Attendant. It is so because these positions are closer to the guest especially the foreign guests than other positions. From this hotel, there are some findings which are presented into four points (based on the questionnaires). Those four points are 1) greeting, 2) offering Help, 3) explaining hotel facilities and general knowledge of city, and 4) responding complains. They are presented as follow.

\section{Greetings}

There are two questions designed for this matter; 1) Do you greet the foreign guests in English? and 2) What expression do you usually use to greet the foreign guests? Asked the first question, all respondents answer "yes". It means that they completely use English expression in greeting. Further, through accidental interview it can be reported that it is a 
must for all personnels to greet foreign guests with English expression. It does not really matter for them. It can be reported as well that commonly the expression used is "Good Morning Sir" or "Good Afternoon, Ma'am", on the other hand some respondents do not only use such an expression, but they also use "Welcome to Novotel" or "Welcome to the Pool Area".

On a particular situation, it was found that a respondent even used "Good Afternoon Mr/Mrs. How are you?" Confirmed this expression, the respondent explained that she had known the guests before (the guests had been staying at the hotel). It is confirmed because it is so strange to express "How are you" at the very first meeting, it is thus acceptable if the situation is like what the respondent explained. Further, there are also some other expressions which are presented in this section. They are expressed as the accompaniment of "Good morning". They are "What can I do for you?", "Can I help you?" and "Anything I can help?" Regarding the anwers in the questionnaire, these expressions are only used by receptionist and operator. The respondents need to do it to ask what they can help for cheking in or out and for reservation. Both positions are the center of welcoming guests face to face or via telephone. Therefore, the hotel personels in both positions have to offer help for the guests coming. Moreover, there is a respondent in operator position saying "Thank you for your reservation". This expression was uttered at the end of phone communication.

Dealing with greeting, the researchers found that there is a respondent using "Good Night" to greet the guest. Culturally, it is not the right greeting in that situation. The right one is "Good Evening". "Good night" is used to end up the conversation and according to Concise English Dictionary this expression is a conventional expression of farewell. This missusage happens because of first language interference and as a matter of the fact that it is because of translation matter. In bahasa Indonesia, the greeting is Selamat Malam, the word malam is translated into night. Therefore culturally the participant used Good Night for Selamat Malam.

\section{Offering Help}

Offering help is not only done by receptionist and operator, but it is also uttered by other respondents at other positions, such as waitress, pool attendant, and Guest Relation Officer (GRO). There are also two questions designed for this matter; 1) Do you offer help to the foreign guests in English? and 2) What expression do you usually use to offer help to the foreign guests? Further, It can be reported that nearly all participants use English to offer help to foreign guests. There is only one respondent answering this matter in Indonesian. Then, the researchers confirmed it to the respondent. Thus it deals with English mastery.

Some various expressions found are "What can I do for you, Sir/Ma'am?", "Can I help you?", "Is there anything I can do for you?", "May I assist you?", "How may I help you?", "Do you need assistance?" It seems that there is no such a conventional expression prescribed to be used. Therefore, each hotel personnel uses their own style. In this case, it will be much better for the hotel to prescribe and standardize the expressions in English so that all personnels will have the standardized expression or the minimum proficiency. Further, especially for the respondents working as Pool attendant, they use the same expression, i.e. "How are you Sir, May I help you?" This expression tells that the one expressing it has known the addresee before. Thus, it is to get closer to the guest, this is something good especially in hotel industries.

\section{Explaining Hotel Facilities and General Knowledge of the City}

Giving information about all hotel facilities and the city in English is not an easy thing for hotel personnel, moreover if they do not have sufficient proficiency of English. This 
matter is also found in Novotel hotel. It can be reported that there are some problems faced by the respondents. Those problems are 1) there are some unfamiliar terms dealing with facilities and it is difficult for the repondents to explain because of lacking of vocabulary; 2) the hotel does not have books/booklets about the city or tourism places written in English, so it still becomes a problem because they have to explain them in English; 3) lacking of English course conducted by the hotel. Concerning with English course, the hotel manager does not do that because of the recruitment system. Hotel requires employees with English ability, thus this becomes the reason why hotel does not provide English course. As the matter of the fact, the researchers found some hotel personnels who find difficulty in explaining hotel facilities and city.

Dealing with this point, there are four questions provided in the questionnaire. The first question is "Do you usually use English to explain hotel facilities and information about city to the foreign guests?" Asked this question, some respondents answer "yes" but some others do not. Then, coming two the second question ("What problem do you find in explaining hotel facilities in English?"), some respondents do not find any difficulties to explain all facilities in English. However, some others feel hard to do so. Even sometimes they mix Indonesian and English, use body language, and show pictures. Moreover, it is found that they use Indonesian because the foreign guests coming can speek in Indonesian.

Further, the third question brings about "What do you explain about city where the hotel is established?" This question requires matters that the respondents explain to the foreign guests who ask about something dealing with the city. Thus, there are four matters commonly found, they are tourism places, culinary, souvenir centers, and traditional foods. Then, asked the fourth question ("What problem you find in explaining the city where the hotel is established?"), some respondents find no difficulty to do this matter while some other respondents get the difficulty. It means that the problem stays the same, it deals with the English proficiency.

\section{Responding Complain}

Generally, the result found for the matter of responding complain is not too different from the previous matter. For responding complain case, the researhers designed two questions; one is closed question ("Do you respond complains from the foreign guests in English?") and another one is open-ended one ("What expression do you usually use to respond complains from the foreign guests?"). Nearly all respondents answer "yes" for the first question, there is one aswering 'no' and there is another one left the question empty (the researchers couldn't make confirmation of it). The one answering "no" explained that she cannot speak English fluently.

\section{Conclusion}

Employing questionnaire to gather the data, this research comes up with several findings. The first matter is dealing with greeting, it is found that all respondents greet the foreign guests with English expression. Further, at two positions, greeting is followed with the expression of offering help. However, there is one expression which is not appropriate, i.e. "Good Night". The common expressions used are "Good Morning/Afternoon/Evening, Sir/Ma'am" then at receptionist, operator, and bellboy positions, it is followed with "Welcome to Novotel hotel" and "What can I do for you?", or "Can I help you?", or "Anything I can help?" The second one is dealing with offering help. It can be reported that there are some versions of the expression meaning that there is no conventional expression standardized by the hotel. Here are the expressions used; "Is there anything I can do for you?", "May I assist you?", How may I help you?", "Do you need assistence?", and some other expressions mentioned previously in the greeting session. The next is about explaining hotel facilities and general knowledge of city. In this case, some participants do not find any 
difficulties, while some others feel hard to do so. There are three major problems found; unfamiliar terms of facilities, no books/booklets about city or tourism places written in English, and no English training for the hotel personnel. Then, the last one is dealing with responding complains. It seems that the same problem appears, i.e. English proficiency.

Moreover, it thus can be concluded that not all hotel personnels have basic competences of hospitality. It is not only by performing good gesture, but it also deals with language. Regarding the findings, it is really suggested to the hotel developer/manager to create the standardized expressions, which can be in from of pocket book so that hotel personnels can have the minimuml insight or in this case the standardized comptetence/proficiency.

\section{Acknowledgement}

Thanks to Hady Duantoro (one of the participants) who administered the questionnaire distribution.

\section{References}

Brunton, M. W. Cameron. 2009. An Evaluation of Students' Attitudes to the General English and Specific Components of Their Course: A Case Study of Hotel Employees. ESP World, Vol 8, Issues 4.

Croker, Robert A. 2009. An Introduction to Qualitative Research. Heigham, Juanita \& Croker, Robert A. (eds.) in Qualitative Research in Applied Linguistics: A Practical Introduction. London: Palgrave McMillan.

Duff, Patricia A. 2008. Case Study Research in Applied Linguistics. New Jersey: Lawrence Erlbaum Associates.

Hai-yan, Kong and Baum, Tom. 2006. Skills and Work in the Hospitality Sector (The Case of Hotel Front Office Employees in China). In International Journal of Contemporary Hospitality Management. Vol. 18 No. 6, pp. 509-518. Emerald Group Publishing Limited.

M. Ariffin, Ahmad Azmi , Maghzi, Atefeh and Norzalita A. Aziz. 2011. Understanding hotel hospitality and differences between local and foreign guests. International Review of Business Research Papers. Vol. 7. No. 1. January 2011. pp. 340 - 349.

M. Blue, George and Harun, Minah. 2003. Hospitality Language as a Professional Skill. English for Specific Purposes 22 (2003), pp. 73-91. Elsevier Science Ltd.

Stake, Robert E. 2010. Qualitative Research-Studying How Things Work. New York: The Guilford Press.

Wilkinson, David and Birmingham, Peter. 2003. Using Research Instruments, a Guide for Researchers. London and New York: Routledge Falmer. 